\title{
Korelasi antara kadar procalcitonin dengan serum transaminase pada pasien sepsis: sebuah studi pendahuluan
}

\author{
Nur Hadi Kuswoyo ${ }^{1}$ Ronald Irwanto Natadidjaja ${ }^{2}$
}

\begin{abstract}
ABSTRAK
\section{LATAR BELAKANG}

Sepsis merupakan suatu respon sistemik terhadap infeksi. Sepsis masih merupakan penyebab kematian utama pada kasus kritis di berbagai penjuru dunia. Central of Disease Control (CDC) pada tahun 2016 mencatat sedikitnya 1.7 juta orang dewasa mengalami sepsis per tahunnya, dengan angka kematian mencapai rata rata 270.000 orang per tahun di Ameriksa Serikat. Procalcitonin (PCT) merupakan pemeriksaan baku emas pada kasus sepsis bakterial. Kejadian sepsis akan menyebabkan terjadinya gagal multi-organ, tak terkecuali terjadi gagal hati. Penelitian ini merupakan sebuah studi pendahuluan, yang mencoba untuk melihat korelasi antara peningkatan PCT dengan peningkatan serum transaminase pada pasien-pasien yang didiagnosis sepsis.
\end{abstract}

\section{METODE}

Penelitian ini merupakan prelimanary study, bersifat analitik observasional dengan jumlah sampel sebesar 36 subyek, dan rancangan penelitian potong lintang di ruang ICU sebuah rumah sakit di Jawa Barat. Pada penelitian ini reduksi perancu dilakukan melalui kriteria inklusieksklusi, dilakukan uji korelasi Spearman setelah terlebih dahulu dilakukan uji normalitas.

\section{HASIL}

Data yang diperoleh rerata usia subjek penelitian adalah $47.5 \pm 3.57$ tahun. Hasil kadar serum transaminase (SGPT) pada pasien sepsis menunjukkan rata-rata $60.4167 \pm 1.65 / \mathrm{mm} 3$. Rata-rata kadar procalcitonin pada pasien sepsis adalah $6.5083 \pm 0.78 \mathrm{ng} / \mathrm{ml}$. Koefisien korelasi yang didapat pada penelitian ini antara kadar serum transaminase PCT dengan SGPT adalah $\mathrm{r}=0.812(\mathrm{p}=0.000)$.

\section{KESIMPULAN}

Penelitian ini merupakan studi pendahuluan yang mungkin bisa memberikan suatu indikasi bahwa pada sepsis awal, sebenarnya sudah mulai terjadi disfungsi hati, dan dari penelitian ini terdapat korelasi yang signifikan antara peningkatan kadar PCT dengan SGPT.

Kata kunci : sepsis, procalcitonin, serum transaminase

\author{
${ }^{1}$ Program Studi Kedokteran, \\ Fakultas Kedokteran, \\ Universitas Trisakti \\ 2 Departemen Ilmu Penyakit Dalam, \\ Fakultas Kedokteran, \\ Universitas Trisakti
}

\section{Korespondensi:}

Ronald Irwanto Natadidjaja Departemen Ilmu Penyakit Dalam, Fakultas Kedokteran,

Universitas Trisakti, Jalan Kyai Tapa No. 260, Grogol, Jakarta Barat Email: ronald@trisakti.ac.id; ronald.irwanto@yahoo.com

J Biomedika Kesehat 2019;2(1):15-19 DOI: $10.18051 /$ JBiomedKes.2019. v2.15-19

pISSN: 2621-539X / eISSN: 2621-5470

Artikel akses terbuka (open access) ini didistribusikan di bawah lisensi Creative Commons Attribution 4.0 International (CC-BY 4.0) 


\section{ABSTRACT}

\section{The corelation between procalcitonin to transaminase serum level in sepsis patients: a preliminary study}

\section{BACKGROUND}

Sepsis is an event of Systemic Inflammation Response Syndrome (SIRS) due to the infection. Sepsin is still the main cause of death on critical-state patient around the word. At least 1.7 million people per year resulted sepsis with 270.000 death per year in USA reported by CDC 2016. Figuring this issue, the Procalcitonin (PCT) stay being a gold standard to judge the sepsis event. Multi-organ failure, including liver failure frequently occured due to sepsis. This study is a preliminary study, which tries to see the correlation between increased PTC with transminases serum in patient that diagnosed with sepsis.

\section{METHODS}

This observastional analytic research done as a cross sectional preliminary study in ICU room of a hospital in West Java for showing the correlation between PCT level to transaminase serum (SGPT) on 36 subjects. Confounding factor reduced by inclution and exclution criteria, continued by spearman correlation analysis before normality test.

\section{RESULT}

Mean age data is $47.5 \pm 3.57$ years old. Mean of PCT level in sepsis patient is $6.5083 \pm 0.78 \mathrm{ng} / \mathrm{ml}$, while the mean oftransaminase serum (SGPT) level each is $60.4167 \pm 1.65 / \mathrm{mm} 3$. The coefficient corelation of PCT to the SGPT show $\mathrm{r}=0.812(\mathrm{p}<0.05)$.

\section{CONCLUSION}

This research showed that liver dysfuunction may indicates the early event of sepsis. The high correlation between PCT and transamnase elevation resulted in this research.

Keywords : sepsis, procalcitonin, transaminase serum

\section{PENDAHULUAN}

Sepsis berdasarkan kriteria dari konsesus American College of Chest Physcians dibagi menjadi tiga terminologi, yaitu sepsis, sepsis berat dan syok septik. Sepsis adalah suatu sindrom klinis yang ditandai dengan adanya infeksi dan respon inflamasi sistemik, sepsis berat adalah infeksi dengan adanya bukti kegagalan organ akibat hipoperfusi, syok septik adalah sepsis berat dengan hipotensi yang persisten setelah diberikan resusitasi cairan dan menyebabkan hipoperfusi jaringan. ${ }^{(1)}$ Data di RSUD Dr. Soetomo Surabaya didapatkan 80 penderita yang mengalami yang mengalami sepsis dari 250 orang yang dirawat di ICU (29\%) selama periode Januari-April 2010.(2) Sepsis menempati urutan ke-10 sebagai penyebab utama kematian di Amerika Serikat dan penyebab utama kematian pada pasien sakit kritis. Kejadian sepsis meningkat hampir empat kali lipat dari tahun 1979-2000, menjadi sekitar 660.000 kasus (240 kasus per 100.000 penduduk). ${ }^{(3)}$

Sepsis dapat menyebabkan disfungsi organ multipel dan salah satu organ yang terkena adalah hati. Kerusakan hati akibat sepsis disebabkan oleh sitokin inflamasi yang akan mengakibatkan perubahan transkipsi gen pada sel hati. Sebagai penanda adanya kerusakan sel hati dapat dilakukan pemeriksaan uji fungsi hati untuk mengetahui tingkat keparahannya. ${ }^{(4)}$ Pemeriksaan fungsi hati pada pasien sepsis dapat menggunakan SGPT yang dianggap lebih spesifik dibandingkan SGOT, karena SGOT dapat meningkat pada kerusakan sel otot jantung atau rangka sementara SGPT tidak meningkat. ${ }^{(5)}$

Sebagai penanda atau sebagai penegakan diagnosis sepsis dapat dilakukan pemeriksaan biomarker sepsis. Procalcitonin (PCT) merupakan biomarker yang paling sering dipelajari dan rutin digunakan dalam praktik klinik dan rekomendasi di berbagai negara. Kadar PCT akan meningkat pada sepsis dan kadar PCT dengan nilai $>2 \mathrm{ng} /$ $\mathrm{ml}$ memiliki sensitivitas tinggi untuk diagnosis sepsis. Meta analisis oleh Uzzan dkk mendapatkan hasil bahwa PCT lebih baik dari pada $C$-reactive protein (CRP) dalam membedakan Systemic Inflammation Response Syndome (SIRS) dan sepsis. ${ }^{(6)}$ Penelitian ini dilakukan sebagai sebuah studi awal untuk mengetahui apakah terdapat hubungan antara peningkatan kadar PCT dengan kadar SGPT pada pasien sepsis.

\section{METODE}

Penelitian ini dilakukan untuk mengetahui korelasi antara kadar PCT dengan SGPT, dengan 
metode analitik observasional dan menggunakan data sekunder. Penelitian dilaksanakan secara potong lintang di sebuah rumah sakit di wilayah Jawa Barat pada bulan Oktober-Desember 2017. Populasi dalam penelitian adalah pasien yang terdiagnosis sepsis dan besar sampel adalah 36 subyek. Pemilihan sampel dilakukan dengan cara consecutive non random sampling.

Pemeriksaan kadar PCT dan SGPT dilakukan pada waktu bersamaan, yaitu pada waktu awal diagnosis sepsis ditegakkan. Reduksi perancu dilakukan melalui pemenuhan kriteria inklusi dan kriteria eksklusi. Kriteria inklusi pada penelitian ini adalah semua pasien yang didiagnosis menderita sepsis pada rekam medis. Kriteria eksklusi pada penelitian ini adalah subyek yang terdiagnosis keganasan, penggunaan steroid lama, subyek yang sedang dalam kemoterapi serta subyek dengan penyakit hati kronik.

Analisis korelasi kadar PCT dengan SGPT dilakukan dengan uji korelasi Spearman menggunakan Statistical Package for Social Science (SPSS) versi 20. Pada penelitian ini tidak dilakukan uji homogenesitas karena homogenisasi sampel telah dilakukan melalui kriteria inklusi dan eksklusi. Etika penelitian disetujui oleh Komisi Etik Riset Fakultas Kedokteran Universitas Trisakti Jakarta dengan nomor 129/KER-FK/ Vii/2017.

\section{HASIL}

Hasil penelitian dari 36 subyek didapatkan sebagian besar berusia $40-59$ tahun (52.8\%) dan berjenis kelamin laki-laki (58.3\%).

Tabel 1. Distribusi subyek berdasarkan usia dan jenis kelamin

\begin{tabular}{|c|c|c|}
\hline Variabel & $n(\%)$ & $\bar{x}$ \\
\hline \multicolumn{3}{|l|}{ Usia (tahun) } \\
\hline$<20$ & $3(8.3)$ & \multirow{7}{*}{$\begin{array}{l}47.5 \pm 3.57 \\
\text { tahun }\end{array}$} \\
\hline $20-39$ & $2(5.6)$ & \\
\hline $40-59$ & $19(52.8)$ & \\
\hline $60-89$ & $12(33.3)$ & \\
\hline Jenis kelamin & & \\
\hline Laki - laki & $21(58.3)$ & \\
\hline Perempuan & $15(41.7)$ & \\
\hline
\end{tabular}

Pada Tabel 2 nilai rerata SGPT adalah $60.4167 \pm 1.65 \mathrm{UI} / \mathrm{L}$ dan rerata PCT adalah $6.5083 \pm 0.78 \mathrm{ng} / \mathrm{ml}$. Uji korelasi Spearman untuk Kadar PCT dengan SGPT mendapatkan hasil nilai $\mathrm{p}=0.000(\mathrm{p}<0.05)$ dengan nilai korelasi $\mathrm{r}=0.812$.
Hal ini menunjukkan terdapat korelasi kuat antara kadar SGPT dengan kadar PCT.

Tabel 2. Hasil pengukuran kadar SGPT dan PCT

\begin{tabular}{lccc}
\hline Karakteristik & $\mathbf{n}(\%)$ & $\overline{\times}$ & $\mathbf{r}$ \\
\hline SGPT (UI/L) & & & \\
$41-45$ & $1(2.8)$ & & \\
$46-50$ & $6(16.7)$ & & \\
$51-55$ & $9(25.0)$ & & \\
$56-60$ & $3(8.3)$ & $60.4167 \pm$ & \\
$61-65$ & $3(8.3)$ & & \\
$66-70$ & $5(13.9)$ & & $0.812^{*}$ \\
$71-75$ & $9(25.0)$ & & \\
Procalcitonin & & & \\
(ng/ml) & & & \\
$<3.5$ & $20(55.6)$ & & \\
$3.6-6.5$ & $2(5.6)$ & $6.5083 \pm$ & \\
$6.6-9.5$ & $2(5.6)$ & $0.78 \mathrm{ng} /$ & $\mathrm{ml}$ \\
$>9.5$ & $12(33.3)$ & & \\
\hline
\end{tabular}

*Uji korelasi Spearman

\section{PEMBAHASAN}

Sepsis selalu berhubungan dengan hipoperfusi dan disfungsi organ. ${ }^{(7)}$ Diagnosis sepsis kemudian ditingkatkan spesifisitasnya melalui criteria predisposisi, insult infection, respone, and organ disfunction (PIRO) untuk gejala dan resiko yang individual. ${ }^{(8)}$

Sebagian besar penderita sepsis menunjukan fokus infeksi jaringan sebagai sumber bakteriemia yang biasa dinamakan bakteriemia sekunder. Sepsis dapat disebabkan oleh kuman gram negatif atau kuman gram positif Sepsis oleh kuman gram negatif kerap disebabkan oleh fokus primer yang berasal dari saluran genitourinarium, saluran empedu dan saluran gastroinstestinum. Sementara itu, sepsis gram positif biasanya timbul dari infeksi kulit, saluran respirasi dan juga berasal dari luka bakar. ${ }^{(9)}$

Sepsis yang terjadi kemudian menimbulkan inflamasi luas. Inflamasi terjadi sebagai tanggapan imunitas tubuh terhadap berbagai stimulasi imunogen dari luar. Inflamasi sesunguhnya merupakan reaksi tubuh untuk menghilangkan dan eradikasi organisme penyebab. Berbagai jenis sel akan teraktivasi dan memproduksi berbagai jenis mediator inflamasi termasuk berbagai sitokin. Mediator inflamasi sangat komplek karena melibatkan banyak sel dan mediator yang dapat mempengaruhi satu sama lain. ${ }^{(9)}$ 
Timbulnya inflamasi menjadi permasalahan utama, karena faktor-faktor infkamasi inilah yang menyebabkan terjadinya disfungsi organ, termasuk disfungsi hati. Amino transaminase tercatat sebagai indikator yang cukup sensitif untuk menilai adanya inflamasi pada hati. Enzim transaminase meliputi enzim SGPT dan SGOT. SGPT tercatat lebih sensitive untuk menilai terjadinya inflamasi di hati, karena secara spesifik hanya dijumpai hati. ${ }^{(5,10,11)}$

Penelitian dilakukan di sebuah rumah sakit di Jawa Barat 36 subyek yang diperoleh dari data dari rekam medis pasien yang pernah dirawat di ICU. Dijumpai perbedaan insidensi penderita sepsis berdasarkan jenis kelamin yang di dapatkan pada penelitian ini. Berdasarkan distribusi menurut jenis kelamin, dijumpai pria sebesar $58.3 \%$ dan wanita $41.7 \%$. Secara populasi wanita memang tercatat mengalami kejadian sepsis lebih rendah disbanding pria. ${ }^{(12-14)}$

Berdasarkan usia subyek didapatkan jumlah terbanyak pada usia 40-59 tahun, yaitu sebanyak $52.8 \%$. Pada beberapa studi, penderita sepsis yang paling sering ditemukan adalah berusia $>65$ tahun, atau terkategori lanjut usia. ${ }^{(15)}$

Pada penelitian ini didapatkan peningkatan kadar PCT sangat patognomonis pada infeksi yang bersifat sistemik. ${ }^{(16,17)}$ Tingginya kadar PCT juga kerap dihubungkan dengan tingkat beratnya sepsis. ${ }^{(18,19)}$ Disfungsi organ, termasuk hati senantiasa terjadi pada sepsis, dimana didapatkan bahwa kadar serum hati meningkat secara signifikan selama sepsis dini, sedangkan disfungsi progesif akan terjadi pada sepsis lanjut. Pada sepsis sering terjadi kolestasis intrahepatik yang nantinya akan menyebabkan gangguan pada transpor asam lemak dan anion organik pada hepatosit. ${ }^{(20)}$

Berdasarkan hasil uji korelasi yang telah dilakukan pada penelitian ini, didapatkan didapatkan $\mathrm{r}=0.812(\mathrm{p}=0.000)$ yang berarti terdapat korelasi yang signifikan antara peningkatan kadar PCT dengan SGPT. Hasil ini belum menunjukkan suatu hubungan sebab akibat, namun bila menjadi suatu indikator dan sebuah penelitian pendahuluan bahwa tingginya kadar PCT berbanding lurus dengan peningkatan kadar AST.

Penelitian ini masih bersifat lokal, dengan jumlah sampel yang kecil, serta belum menunjukkan sebuah hubungan sebab akibat yang kuat, namun merupakan suatu studi awal yang menunjukkan terdapat hubungan peningkatan PCT dengan SGPT pada pasien sepsis secara signifikan.

Saran untuk peneitian berkelanjutan dengan metode prospektif akan sangat baik bila dilaksanakan dengan uji diagnostik untuk mendapatkan hasil yang lebih representatif.

\section{KESIMPULAN}

Penelitian ini merupakan studi pendahuluan yang bisa memberikan suatu indikasi bahwa sebenarnya pada sepsis awal sudah mulai terjadi disfungsi hati. Hal ini mungkin bisa menjadi sebuah indikator dan membantu para klinisi di rumah sakit, bahwa pasien yang bergejala infeksi namun tidak tersedia pmeriksaan PCT, maka peningkatan nilai SGPT bisa menjadi suatu indikator kewaspadaan akan kemungkinan terjadinya sepsis.

\section{UCAPAN TERIMA KASIH}

Ucapan terima kasih kepada Pimpinan beserta karyawan RSUD Banjar Patroman dan semua pihak yang telah membantu penelitian ini.

\section{DAFTAR REFERENSI}

1. Dellinger RP, Levy MM, Rhodes A, et al. Surviving Sepsis Campaign: International Guidelines For Management Of Savere Sepsis And Septic Shock: 2012. Crit Care Med 2013; 41(2): 580-637. doi: 10.1097/CCM.0b013e31827e83af

2. Ekowati L, Aryati, Hardiono. Limfosit T CD4+ sebagai peramal perjalanan penyakit pasien yang mengalami sepsis. Indonesia Journal of Clinical Pathology and Medical Laboratory 2013;19(3): 178-84 DOI: http://dx.doi.org/10.24293/ijcpml. v19i3.418

3. Luhulima D, Hidayati W, Rejeki I, et al. Eosinopenia dan procalcitonin dalam sepsis. Indonesia journal of clinical pathology and medical laboratory 2013;19(2):119-155. DOI: 10.24293/ ijcpml.v19i2.1067

4. Suryaatmadja M. Pemeriksaan Laboratorium Uji Fungsi Hati. Buletin ABC 2009;11:2-8.

5. Nesseler N, Launey $\mathrm{Y}$, Aninat $\mathrm{C}$, et al. Clinical review: The liver in sepsis. Crit Care 2012;16(5):235. DOI: $10.1186 /$ cc11381

6. Jin $M$ and Khan A. Procalcitonin: Uses in the Clinical Laboratory for the Diagnosis of Sepsis. Laboratory Medicine 2010; 41(3):173-7. https://doi.org/10.1309/LMQ2GRR4QLFKHCH9

7. Kibe S, Adams K, Barlow G. Diagnostic and prognostic biomarkers of sepsis in critical care. J Antimicrob Chemother 2011; 66: 33-40. doi: $10.1093 / \mathrm{jac} / \mathrm{dkq} 523$

8. Robert SM, Halstead ES, Carcillo JA, et al. Definition, epidemiology and pathofisiology. The Open Inflamation Jurnal. 2011;4:16-23. DOI: $10.2174 / 1875041901104010016$ 
9. Sudoyo AW, Setiyohadi B, Alwi I, et al. Buku Ajar Ilmu Penyakit Dalam Jilid I. 5th ed. Jakarta: Interna Publising; 2009.

10. Pratt DS, Kaplan. Laboratory Tests. In Schiff's Diseases Of The Liver. $9^{\text {th }}$ ed. Philadelpia: Lippincott Williams and Wilking; 2003.

11. Isselbacher, Braunwald, Wilson, et al. Harrison Prinsip-prinsip Ilmu Penyakit Dalam, Alih bahasa Asdie AH. 13 ${ }^{\text {rd }}$ ed. Jakarta: EGC; 2012

12. Melamed A, Sorvillo FJ. The Burden Of Sepsis Associaated Mortality In The United States From 1999 To 2005: An Analysis Of Multiple Cause Of Death Data. Crit care 2009; 13(1): R28. doi: $10.1186 / \mathrm{cc} 7733$

13. Girald TD, Opal SM, Ely EW. Insigt Into Severe Sepsis In Older Patient: From Epidemiologi To Evidence Based Management. Clin Infect Dis 2005; 40(5): 719-27. DOI:10.1086/427876

14. Angele MK, Frantz MC, Chandy IH. Gender And Sex Hormones Influence The Response To Trauma And Sepsis: Potential Therapeutic approaches. Clinics 2006; 61(5): 479-88. http:// dx.doi.org/10.1590/S1807-59322006000500017

15. Fenty, Virginia DM. Hubungan Procalcitonin dan Gambaran Morfologi Leukosit Pada Infeksi Bakterial. Jurnal Farmasi Sains Dan Komunitas 2014; 11(2): 81-5. DOI: http://dx.doi.org/10.24071/ jpsc. 112104

16. Assicot M, Gendrel D, Carsin H, et al. High serum procalcitonin concentrations in patients with sepsis and infection, Lancet 1993; 341:515-8. DOI:https:// doi.org/10.1016/0140-6736(93)90277-N

17. Eberhard OK, Langefeld I, Kuse ER, et al. Procalcitonin In The Early Phase After Renal Transplantation-Will It Add To Diagnostic Accuracy? Clin Transplant 1998;12(3):206-11.

18. Ghorbani G. Procalcitoninrole Role In Differential Diagnosis Of Infection Stages And Non Infection Inflamation. Pakistan Journal Of Biological Sciences 2009; 12(4): 393-6. DOI: 10.3923/ pjbs.2009.393.396

19. Nasronudin, Usman H, Vitanata. Perubahan Mediator Selama Perjalanan Sepsis. Dalam: Sepsis. Penyakit infeksi di Indonesia. Surabaya: Universitas Airlangga; 2007: 257-62.

20. Daulay DG, Supriatmo, Sinuhaji AB. Hepatitis Akibat Penyakit Sistemik. Sari Pediatri 2007; 8(8): 294-8 